\title{
Properties of Leno Fabric as Stab Resistant Clothing Material
}

\author{
SaKaguchi Akio *, Hagiwara Shusei, Kimura Hirokazu, Bao Limin, Morikawa Hideaki \\ Faculty of Textile Science and Technology, Shinshu University, 3-15-1 Tokida, Ueda, Nagano 386-8567, Japan
}

Received 4 April 2017; accepted for publication 24 July 2017

\begin{abstract}
Protective clothing is an indispensable equipment for guards, police officers and so on. Although in Japan, the Firearms and Swords Control Law is strictly enforced, nails, ice picks, and such daily goods with sharp tips are not subjected to the law. Ordinally stab proof vests were comprised by metals, thus they are very heavy and poor at air ventilation. Recently, textile materials made of high performance fibers attract attentions. Nevertheless, during stabbing, the interlace points of warps and wefts slide off from their positions without yarn breakage. Hence, we cannot obtain products with high performance as we expected from raw material's properties. In this paper, we discussed a leno fabric. Traditionally, they have been considered to be a thin, light, and sheer fabric for summer clothing. We have noticed that leno fabrics have a level of strength even though their lightness and high air ventilation. In leno fabrics, the intersection points of warps and wefts are locked by crossing of the paired warps. Such locking structure makes leno fabrics durable. In the experiment, air ventilation and stab resistance was tested and compared with an ordinally fabric. The results show that the air ventilation performance of the leno fabric is much higher than the ordinally fabric of similar weight. Additionally, stab properties of the leno fabric are not inferior in comparison with the ordinally fabric. Thus, we conclude that leno structure is a possible technique to design stab proof fabrics for protective clothing.
\end{abstract}

Key Words : Leno fabric, Stab resistance, Protective clothing, High performance textile

\section{絡み織物の耐突刺し防護服素材としての特性}

坂口明男 *, 萩原秀成，木村裕和，鮑力民，森川英明

信州大学繊維学部

\section{1. 緒 言}

警察官等が安全に職務を遂行する上で防護服は重要な装備 である、日本においては銃刀法が徹底されているため, 銃や 剣などの武器によるリスクは低い。しかし，アイスピックの ように銃刀法の規制外であっても鋭利な先端を持ち危険なも のもある．現行の防護服は金属板を鱗状に並べることで耐刃 性・耐突刺し性を持たせる構造になっている. 比較的安価に 高い防護性が確保できるという長所があるが, 一方で金属な ので重く, また通気性も乏しいため, それを着用しての作業 は負担が大きいものとなっている。

これに対してアラミド繊維などの高強度繊維織物で防護服 を作製することも検討されてきた。銃弾などに対して高強度
繊維織物は一定の効果があることが知られている。銃弾に比 べて刃物は人力で操作するためその運動エネルギーは大幅に 小さいが非常に狭い面積にエネルギーが集中して加わるため その防護は容易でない [1]. さらに織物の問題点として鋭利 な先端を持つ物で突刺した時に織目が寄ってしまうために高 強度繊維本来の性能が十分に防護性能に寄与していないとい うことが指摘されている [2].この織目が寄るという現象の ために, 織物構成繊維が切断していないのにアイスピック等 の凶器が貫通してしまうことがある。このようなことが起こ るのは, 通常の織物では経糸と緯糸が交錯してできているた めにその接触摩擦のみで互いを保持し合うという構造になっ ており, 繊維の切断に要するよりもはるかに小さな力で織物 を構成する糸を横方向に移動させることが可能であるからで

* 連絡先：信州大学繊維学部 386-8567 長野県上田市常田 3-15-1

E-mail : aksakag@shinshu-u.ac.jp, Tel : +81-268-21-5387, Fax : +81-268-21-5318 
Table 1 Parameters of samples.

\begin{tabular}{ccc}
\hline Fabric & Leno & Crepe de Chine \\
\hline Weight, g/m ${ }^{2}$ & 65.8 & 64.0 \\
Thickness, mm & 0.27 & 0.20 \\
\hline Density, threads/cm & 29.6 & 71.2 \\
Warp & 14.0 & 39.0 \\
Weft & \\
Yarn Thickness, tex & $6.2 \times 3$ (Stationary end) & 10 \\
Warp & $6.2 \times 2$ (Crossing end) & 10 \\
Weft & 21 & \\
\hline
\end{tabular}

ある。これを防止するためには織物密度を高くし, さらに織 物を樹脂などで処理して織目を接着するなどの対策が考えら れるが，衣服としての通気性が劣化してしまう。

一般に織物は厚く高密度なものほど丈夫であり，薄く低密 度ならば強度が不足するものである。しかし，古来の繊維技 術の一つに非常に薄く低密度ながら一定の強度を持つ, 絡み 織がある [3]。主に絹で製造され，薄地で通気性に富むため 1000 年以上前から夏物衣料材料として重用されてきている. 絡み織では通常の織物と違い, 2 本 1 組の経糸が互いに交差 しながら緯糸が織り込まれるという独特の構造をしている. このため織目が粗くとも織目が寄るということがない. 著者 らはこの絡み織の特徵が織物の耐突刺し防護性に有利に作用 し, 現代の防護服の要求, 即ち織目が寄りにくく, 軽く, か つ通気性に富むという機能を高度に両立できると考えた。今 回はこの絡み織の防護服素材としての特性について検討した ので報告する。

\section{2. 実験}

\section{1 試料}

試料として市販の絡み織物の駒紗とクレープデシンを用い た。防護服では布を重ね合わせて使用するため単位面積当た りの重量である目付量が軽い布が望ましい。したがって今回 はほほ同等の目付の布により比較を行うことにした。実験に 先立ち織物の織密度, 構成糸太さなどを調査した。その結

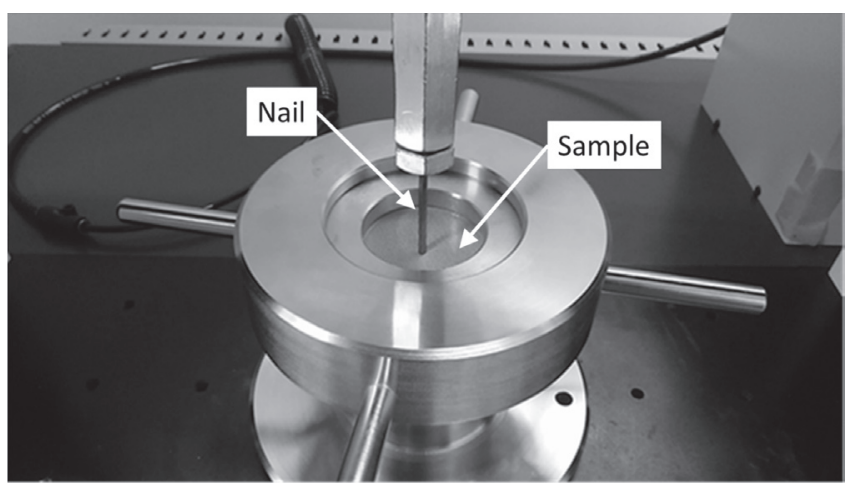

Fig. 1 Stab testing equipment.
果を Table 1 に示す，表中の絡み織物の経糸の太さであるが 絡み織物には地経糸と絡み経糸が一組になっており, 前者は 6.2tex の糸を 3 本束ねた構成であり，後者は同様に6.2tex の 糸を 2 本引きそろえたものであったことを示している。

\section{2 通気抵抗試験}

絡み織物の通気抵抗は経験的に大幅に低いことが知られて いるが今回の試料間でどの程度の差があるのかを調査するた め通気抵抗試験を実施した。実験には通気抵抗試験機 (KESF8-AP, カトーテック) を用いた。両方の織物について重ね枚 数を $1,2,4,8$ の 4 段階に変化させ，その時の通気抵抗を 10 回ずつ測定した。

\section{3 突刺し 試験}

耐突刺し防護性能を検討するため突刺し試験を行った。JIS L 10968.18 .2 では織物及び編物の破裂試験方法が規定されて いる。 これを参考に, 破裂試験の押し棒を直径 $3 \mathrm{~mm}$ の市販 の丸釘に変えた試験装置を開発した。試験器の構成を Fig. 1 に示す，通常の木工用丸釘の先端形状は Fig. 2a に示すよう に四角錘である。一方でアイスピックのようなものは先端が 円錐に近い形態をしている.そこで釷の先端を Fig. $2 b$ に示 すように円錐形に加工したものについても同様に試験に用い た。突刺し速度は $100 \mathrm{~mm} / \mathrm{min}$ とした。試験中, 突刺しに対 する布の抵抗力である耐突刺し抵抗力は釘を取り付けたロー ドセルにより連続的に測定し, 突刺し深さとの関係をデータ として得た。試料の重ね枚数は $1,2,4,8$ 枚の 4 段階に変え, 各条件で 10 回ずつの試験を行った.

\section{4 最大耐突刺し 抵抗力}

上記の試験では釘を布に突刺していくと徐々に耐突刺し抵 抗力が増加し, 最大に達した後に釷が布を貫通して抵抗力が 急激に下がる。この最大值が試験条件によりどのように変化 するかについて検討した。

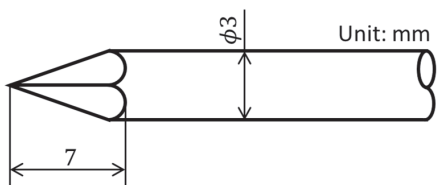

(a) Pyramidical tip

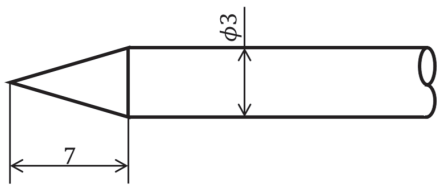

(b) Conical tip 


\section{5 貫通エネルギー}

突刺し試験結果について突刺し深さを横軸に，耐突刺し抵 抗力を縦軸にとると曲線が描かれる。この曲線と横軸で囲ま れた部分の面積は突刺しに要したエネルギーに相当する。釘 が貫通すると大幅に抵抗力が下がるのでそこまでのエネル ギーを貫通エネルギーとして求め, 耐突刺し防護性の指標と して比較した

\section{6 試験結果の検討}

最大耐突刺し抵抗力と貫通エネルギーは重ね枚数とともに 増加するがその度合いは単純な比例とは限らず，例えば 8 枚 重ねた時に必ずしも 8 倍になるとは限らない.そこで今回は べき関数

$y=b x^{a}$

を仮定して検討した（1）式中の $x$ は重ね枚数であり $y$ が最 大耐突刺し抵抗力または貫通エネルギーに対応する。した がって，(1) 式中の $b$ は 1 枚の時の最大耐突刺し抵抗力また は貫通エネルギーに対応する（1）式を両対数グラフにプロッ 卜すると，直線が描かれる，重ね枚数の指数部である $a$ がこ の直線の傾きに対応し，これが 1 よりも小さければ重ね合わ せても枚数の分だけの効果が得られず，逆に 1 より大きけれ ば重ね合わせた枚数以上の効果が見られたことになる。

\section{3. 結果と考察}

\section{1 通気抵抗}

Fig. 3 に通気抵抗試験の結果を示す。いずれの試料におい ても重ね枚数が増加するとほぼ比例して通気抵抗は増加し た。駒紗とクレープデシンを比較すると同等の重ね枚数なら ば駒紗の通気抵抗はクレープデシンの 100 分の 1 程度の結果 となった。今回の試料の目付は同程度であるがクレープデシ

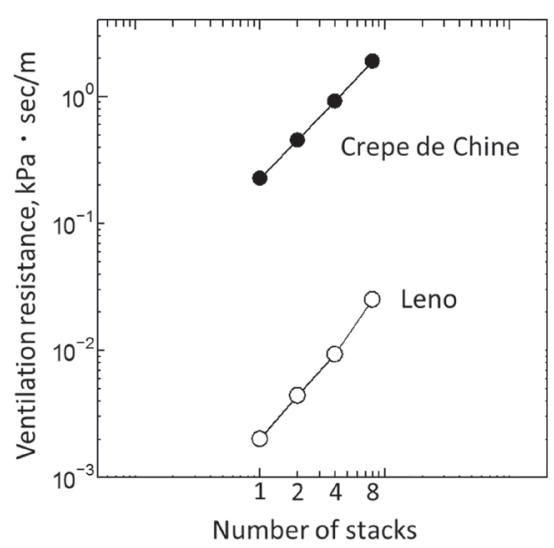

Fig. 3 Ventilation resistance of sample fabrics.

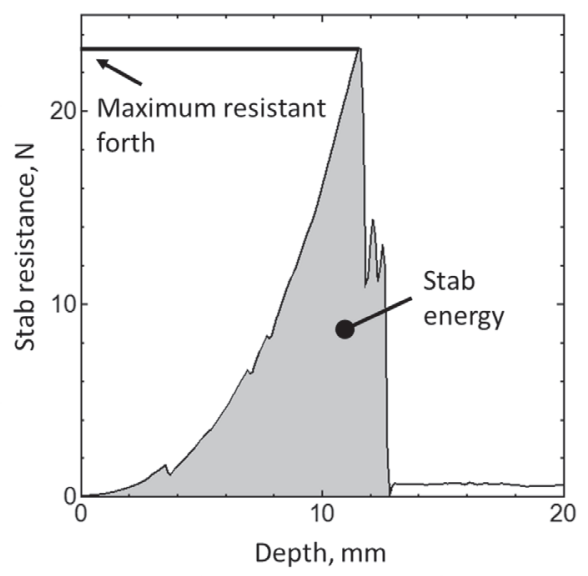

Fig. 4 An example of stab resistance-depth chart.

ンは細い糸が高密度に織り込まれているため糸同士の隙間が 狭い.このことが通気抵抗の大きな差になったと考えられる。 絡み織物の通気性が良い, すなわち通気抵抗が低いことは古 くから常識的に知られていたが，今回それをデータで裏付け ることができた。

\section{2 突刺し試験}

Fig. 4 に突刺し試験における耐突刺し抵抗力 - 変位曲線の 一例を示す．今回の試験では試料と釷先端が少し離れた状態 から試験を開始し，耐突刺し抵抗力が $5 \mathrm{cN}$ を初めて超えたと きに釘先端が試料表面に達したと規定した。その後, 釘を押 込んでいくと布は突刺しに対して抵抗し，その力がロードセ ルで検出される。突刺し深さが深くなると耐突刺し抵抗力も 大きくなるが限界に達すると釘が試料を突き破り，抵抗力は 大幅に下がる. 最大の抵抗力はこのグラフの最高点の高さに 対応する。また，貫通エネルギーは釷が試料を突き破るとこ ろまでのグラフと $x$ 軸で囲まれた部分の面積に対応する.

\section{3 最大耐突刺し 抵抗力}

重ね枚数を横軸に, 最大耐突刺し抵抗力を縦軸にとって 両対数目盛でグラフをプロットした結果を Figure 5 に示す. Fig. 5a は釘先端が四角錘形，Fig. $5 \mathrm{~b}$ は釘先端が円錘形の場合 である。図中の直線と式は実験結果をべき関数で近似した結 果である。べき関数の指数部が 1 である場合には織物重ね枚 数に比例して最大耐突刺し抵抗力も増加したことを示してい る.

結果を見るといずれの場合もお㧍むねべき関数でよく近似 できている，釷先端が四角錘形の場合は駒紗のほうがクレー プデシンよりも大きな耐突刺し抵抗力を示したが，重ね枚数 を増加するとその差は接近してきた。また，釘先端が円錐形 の場合には両者の差は少なかった。さらに釘先端が円錐形で 駒紗を突刺した場合を除いてべき関数の指数部は 1 を下回っ た。これは重ね枚数を増やしてもそれに見合っただけ最大耐 突刺し抵抗力が増加しないことを示している。これを考察す 


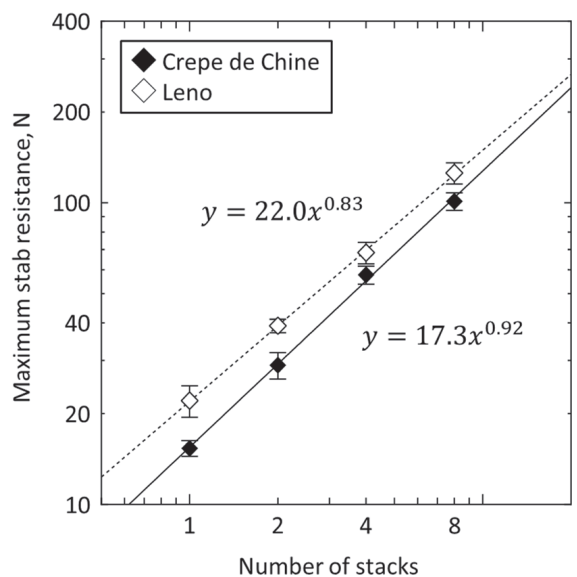

(a) Pyramidical tip.

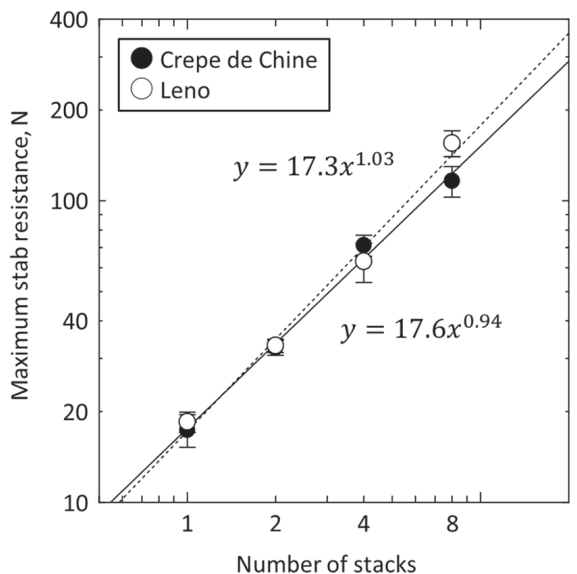

(b) Conical tip.

Fig. 5 Maximum stab resistance.

るために極端なケースとして重ねた織物の間に十分な空間が あると考える。すると 1 枚ずつ貫通していくために最大耐突 刺し抵抗力は重ね枚数によらず 1 枚の時と変わらなくなるは ずである，今回はこの様な十分な布間の隙間がないので重ね 枚数の増加とともに最大耐突刺し抵抗力は増加したが, 完全 に重㸚わせた布が一体化しているわけではないので重ね枚 数に比例した増加にならなかったと考える.

\section{4 貫通エネルギー}

重ね枚数を横軸に, 貫通エネルギーを縦軸にとって両対数 目盛でグラフをプロットした結果を Fig. 6 に示す. 図に示す 通り貫通エネルギーに関してもべき関数は良くあてはまって いる，貫通に要するエネルギーは釷の先端形状にかかわらず 駒紗のほうがクレープデシンを上回った。ただし Fig. 6a に 示すように釷先端が四角錘形で重ね枚数を増加させると両者 の差はなくなってくる。べき関数の指数部に注目するといず
れに扔いても值が1よりも大きくなった，即ち重ねた枚数以 上に貫通に要するエネルギーは増加した，最大突刺し抵抗力 の時と同様に重ねた布が個別に貫通されていく場合には単純 に貫通に要するエネルギーは枚数に比例して増加すると考え られる。実際には布が重なり合うことで一枚目の布を貫通す る前にそれ以降の布にも力が働き始めるが，布には厚みがあ るので釷先端で押される部分の曲率が小さくなり，一枚目よ りも広い面で力を受け止めることになる。 その結果，突き破 るのに必要なエネルギーが増加したものと考える。この効果 は先端形状の違いに影響を受け，絡及織物の場合先端が四角 鍾形の場合には効果が少なかった。このように織物の種類だ けでなく釷先端の形状によっても耐突刺し防護特性が変化す る.

\section{4. 結 言}

絡み織技術の耐突刺し防護原理について検討した。同等の

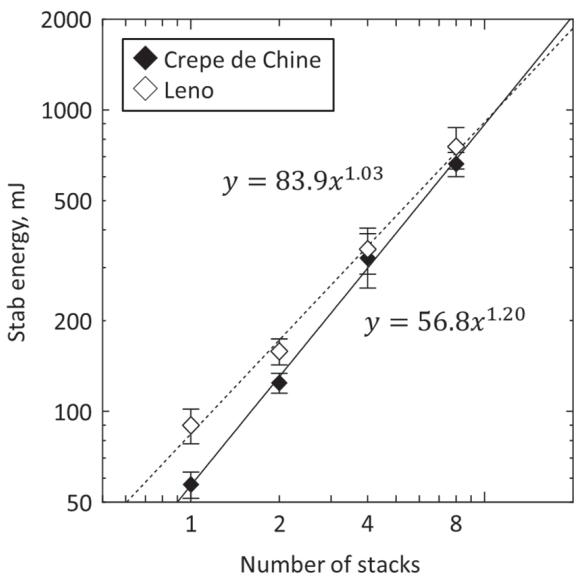

(a) Pyramidical tip.

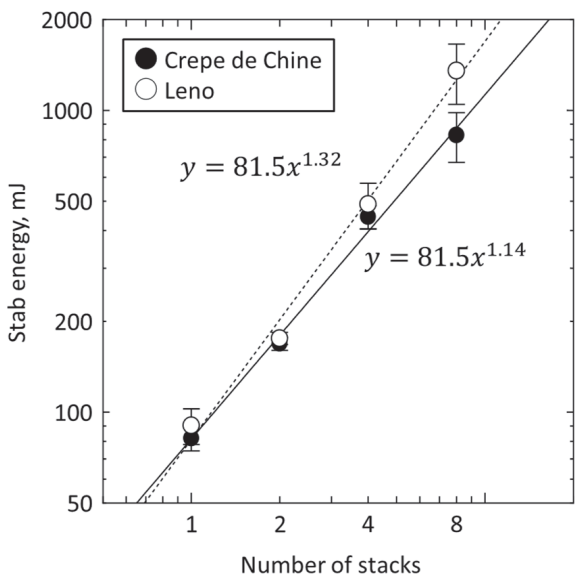

(b) Conical tip.

Fig. 6 Stab energy. 
目付量の平織物と絡み織物を比較すると, 最大耐突刺し抵抗 力と貫通エネルギーの観点から見て絡み織物のほうが防護性 が高いケースが多いが重ねていくとその差が少なくなる場合 もあった。一方で衣服として求められる性能の一つである通 気性は大幅に絡み織物が優れており，通気性を保ちながら防 護性を高める方法を検討する上で絡み織は有効であると考え る.

\section{謝辞}

本研究の実施に当たり信州大学繊維学部技術部の林光彦氏 と篠原和夫氏に技術的な支援をいただいたことに感謝申し上
げる。本研究は JSPS 科研費 JP15H01789 及び JP16K12699に より実施した。

\section{References}

[1] Horsfall I (2012) "Advances in military textiles and personal equipment”, Sparks E (Ed.), 3-20, Woodhead Publishing, Cambridge UK.

[2] Bao L, Sato S, Morikawa H, Soma S (2016) J Text Eng, 62, $37-42$.

[3] Chen Y (2011) "Specialist yarn and fabric structures Development and applications", Gong RH (Ed.), 118-140, Woodhead Publishing, Cambridge UK. 